Copyright (C) 2020 University of Bucharest Printed in Romania. All rights reserved

ISSN print: $1224-5984$

ISSN online: 2248-3942
Rom Biotechnol Lett. 2020; 25(2): 1396-1406 doi: $10.25083 / \mathrm{rbl} / 25.2 / 1396.1406$

Received for publication, September, 20, 2019

Accepted, January, 29, 2020

Original paper

\title{
Analysis of RASFF notifications on contaminated dairy products from the last two decades: 2000-2020
}

\section{ALINA NARCISA POSTOLACHE ${ }^{1}$, SORIN SERGIU CHELMU ${ }^{2 *}$, ADINA MIRELA ARITON ${ }^{1}$, MITICĂ CIORPAC ${ }^{1}$, CECILIA POP ${ }^{3}$, MARIUS MIHAI CIOBANU ${ }^{4}$, ȘTEOFIL CREANG $\breve{A}^{1,4}$}

\footnotetext{
${ }^{1}$ Research and Development Station for Cattle Breeding Dancu, 707252, Iaşi, Romania

${ }^{2}$ Bioterra University Bucharest; Faculty of Agrotourism Management, 81 Gârlei Street, $1^{\text {st }}$ District, Bucharest, Romania

3“"Ion Ionescu de la Brad" University of Agricultural Sciences and Veterinary Medicine, Faculty of Agriculture, 3 Mihail Sadoveanu Alley, Iaşi, 700490 Iaşi, Romania

4“Ion Ionescu de la Brad" University of Agricultural Sciences and Veterinary Medicine, Faculty of Animal Husbandry, 3 Mihail Sadoveanu Alley, Iaşi, 700490 Iași, Romania
}

\begin{abstract}
EU is the world's leading exporter of cheese and one of the world's top three suppliers of processed milk. Instruments such as those of the European Food and Feed Rapid Alert System (RASFF) play an increased role in consumer protection along global supply chains.

On these premises, the objective was to analyze the status of RASFF notifications for milk and milk products food category, within the time frame $2000 \div 2020$. The majority of dairy products were notified by France, Germany and Italy. Cheese was the most notified of all dairy products $(84.43 \%)$, most of the transmitted food safety hazards being: microbial contaminants $(68.4 \%)$, foreign bodies, adulteration / fraud, organoleptic aspects and residues of veterinary medicinal products. Notifications was usually based on company's own check $(35.47 \%)$ and official controls on the market (34.32\%). A risk decision was not usually made, the taken actions including mainly recalls and withdrawals (56.95\%) or destruction (7.96\%).

The results of this study can be used to prioritize and target research areas to identify key food safety topics, in particular fraudulent ones, to raise the awareness of the consumer and to promote and strengthen food safety legislation, with a focus on the European dairy sector.
\end{abstract}

Keywords Food safety hazards, milk and milk products, RASFF.

To cite this article: POSTOLACHE AN, CHELMU SS, ARITON AM, CIORPAC M, POP C, CIOBANU MM, CREANGĂ Ș. Analysis of RASFF notifications on contaminated dairy products from the last two decades: 2000-2020. Rom Biotechnol Lett. 2020; 25(2): 1396-1406. DOI: $10.25083 / \mathrm{rbl} / 25.2 / 1396.1406$

*Corresponding author: SORIN SERGIU CHELMU, Bioterra University Bucharest; Faculty of Agrotourism Management, 81 Gârlei Street, $1^{\text {st }}$ District, Bucharest, Romania

E-mail: sschelmu@gmail.com

ALINA NARCISA POSTOLACHE, Research and Development Station for Cattle Breeding Dancu, 707252, Iași, Romania

E-mail: narcisa.postolache@gmail.com 


\section{Introduction}

The increasing complexity and globalization of our food supply chain has posed new challenges to ensure the safety and quality of food products on the market. To cope with this challenge, a broad spectrum of hazards that may contaminate food need to be controlled by both food producers and authorities in accordance with Regulation (EC) No. 853/2004 and minimum HACCP system. In this background, the Rapid Alert System for Food and Feed (RASFF) is a useful tool that has been in use for more than 30 years (BÁNÁTI \& KLAUS [3]) and has grown exponentially in terms of its effectiveness (BOUZEMBRAK \& MARVIN [4]).

The legal basis for the Rapid Alert System for Food and Feed (RASFF) is Art. 50 of Regulation (EC) No. $178 / 2002$. Furthermore, all the details of RASFF notifications from portal comply with Commission Regulation (EU) No. 16/2011 of 10 January (EC 2011).

As regards its way of continental operating, when public health risks are detected in the food chain, RASFF facilitates the exchange of information between its members (EU28), the European Commission, the European Food Safety Authority (EFSA), the European Free Trade Association (EFTA), Surveillance Authority (ESA) plus the following countries: Norway, Iceland, Liechtenstein and Switzerland (JAUD et al, [14]). Its efficacy is based on its simplicity of operation and the member's legal obligation to notify the European Commission or intervene when the serious food risk happens (PARISI et al [23]; PIGLOWSKI [27]).

Continuous improvement of the RASFF system is a mandatory direct result of research findings on network vulnerabilities, expressing mixed opinions such as: it is mainly a method for reaction after the fact (HIRSCHAUER \& ZWOLL [10]); incidents that have never cross the border may not be reported (THOMSON et al, [29]) or the fact that it is not a proactive method to avoid hazardous food entering the market (BÁNÁTI [3]; VAN DE BRUG et al [33]).

On the other hand, RASFF database is recommended as an efficient tool for up-to-date knowledge and future hazard identifying predictions (KLETER et al [15]; BANACH et al [1]; BOUZEMBRAK \& MARVIN, [4]; LÜTH et al [12])

Several authors have already made interesting studies concerning limited time periods, showing at the same time that the concept of particular indicators could be useful when thinking about emerging issues and predictive approaches (HRUSKA \& FRANEK [13]; KLETER et al [15]; ZHANG et al [37]; JAUD et al [14]).

Specific literature on food safety in dairy products argues that monitoring should preferably focus on its most relevant food safety hazards throughout the supply chain. A 2016 literature review of the European dairy supply chain found that microbiological hazards were found more frequently than chemical and physical hazards, identifying the relevant ones for each category (VAN ASSELT et al [32]).
Knowing that, this research paper seeks to draw an up-to-date picture of the RASFF notifications from the last two decades to ensure that the present and future predictions are properly represented.

\section{Methodology}

Information's were extracted from the RASFF portal server (European Commission, 2019b). Search criteria for original RASFF notifications, concerning European countries (but not limited only at), independent of the country involved, were considered: period "notified between 01/01/2000 31/12/2019", product type: "food" and product category: "milk and milk products - MMP", the remaining criteria being excluded from filtering with the scope of having a complete dataset (query from 31/12/2019, Version 1.9).

Subsequent, this database has been processed through Microsoft Excel 2019 (Microsoft Corp., Redmond, USA) to produce descriptive statistics, including frequency distributions (pivot filtering tables). The principal filter classes for further MMP data interpretation were date (by year), hazard category, notification classification, notification basis, country's role (origin or notification by), action taken and risk decision. All 1012 original RASFF notifications were included in creating the database set of 1043 cases, some involved notifications containing more than one issue or country of origin.

The chord diagram (Fig. 4) development script code used can be found at https://github.com/mattflor/chorddiag. Online articles from Science Groups, Scopus, Google Scholar databases and official EU repositories were used as references. â

\section{Results and Discussion}

\section{a) RASFF notifications}

Currently, RASFF notifications are studied from a statistical point of view and results are provided through an annual report. Over the last 20 years, a total of 56620 notifications have been reported through the system, with $19.70 \%$ more in the last decade, $59.85 \% \quad(n=33886)$ compared to the $2000 \div 2009$ period $(40.15 \%, n=22734)$ (Fig. 1). The most frequent notifications have been attributed to the following categories of products: nuts, nut products and seeds (18.54\%); fruits and vegetables $(14.81 \%)$ and fish and fish products $(10.45 \%)$ for a total of $43.79 \%$. In the second block there are 8 categories of food products, with each shareholder between $3.5 \div 5.5 \%$ of all RASFF notifications, as defaulted: meat and meat products: other than poultry $(5.44 \%)$; poultry meat and poultry meat products $(5.30 \%)$; food contact materials $(5.21 \%)$; herbs and spices $(5.12 \%)$; dietetic foods, food supplements, fortified foods $(4.57 \%)$; cereals and bakery products $(4.02 \%)$; feed materials $(3.70 \%)$ and crustaceans and products thereof $(3.56 \%)$. The third block consists of 30 categories of food products, with a total of $19.28 \%$ $(\mathrm{n}=10915)$, ranging from $0.07 \div 1.90 \%$ each.

Within this group, the category of milk and milk products is the second, information which was actively involved in data selection of RASFF product category 
notifications, particularly given that the European Union is the world's leading exporter of cheese and one of the world's top three suppliers for dairy exports (cheese, skimmed milk powder and packed milk) (TROPEA [30]).

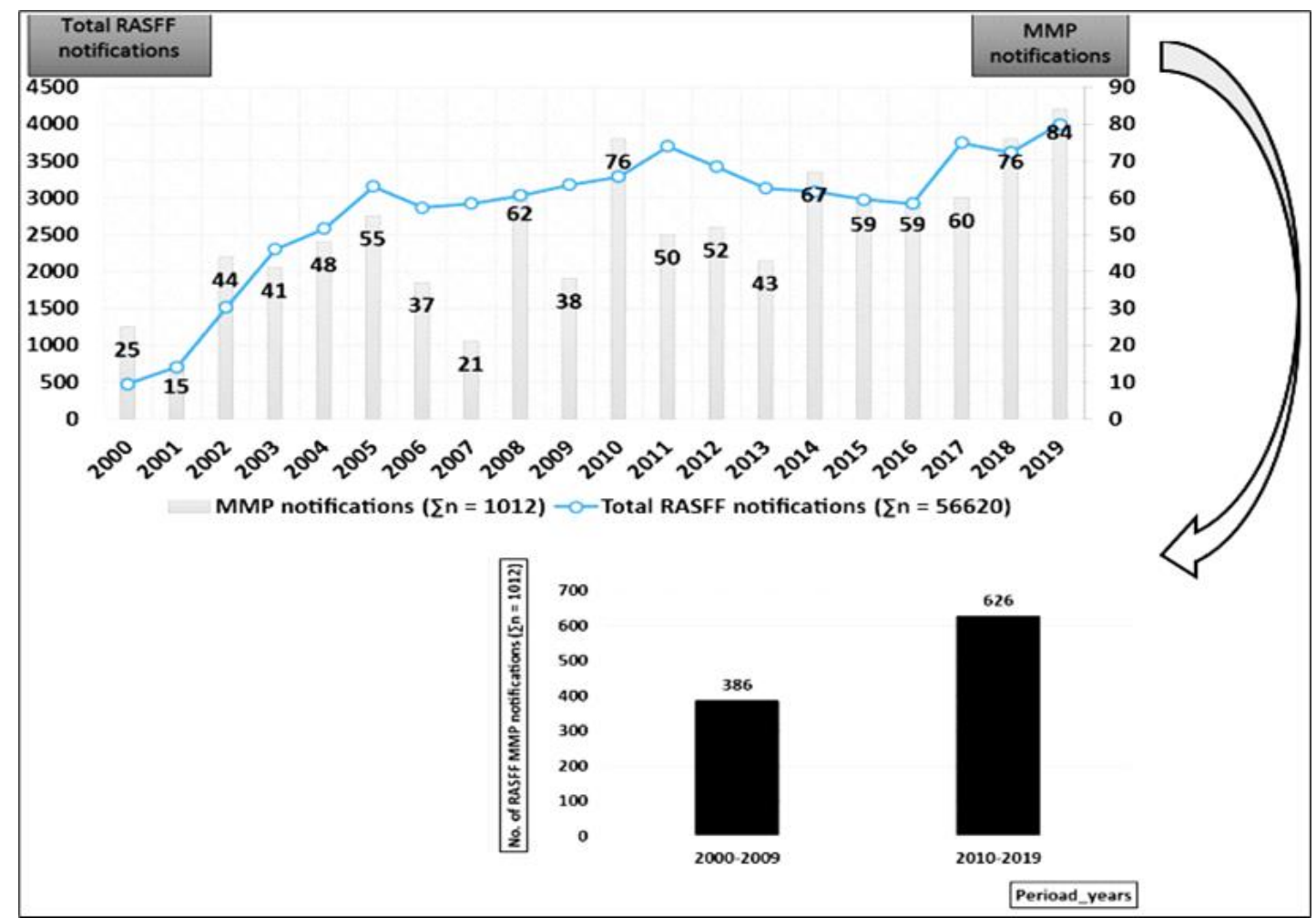

Figure 1. MMP RASFF category notifications from overall RASFF notifications.

Although the knowledge is nearly up-to-date due to the annual statistics provided by RASFF, there is a data discrepancy in the 4-year timeframe analyzed (2000-2001 \& 2015-2016), even if some data are accessible from 1999 to 2014 in relation to the total number of original notifications $(\mathrm{n}=698)$.

\section{b) MMP RASFF original notifications $(\mathrm{N}=1012)$}

In the last 20 years, the original notifications relating to the subject of this review form the core of the third block, with $1.79 \%(n=1012)$ of the total RASFF notifications $\left(13^{\text {th }}\right.$ in a decreasing sense), of which $59.09 \%$ were classified as alert $(\mathrm{n}=598), 20.36 \%(\mathrm{n}=206)$ as information, $10.67 \%$ $(\mathrm{n}=108)$ as information for follow-up, $7.71 \%(\mathrm{n}=78)$ as information for attention and $2.17 \%(n=22)$ as border rejection. Overall, there have been an increase with $23.84 \%$ in MMP notifications over the last decade $(61.92 \%, \mathrm{n}=626)$ compared to $2000-2009$ (38.08\%, $\mathrm{n}=386)$, more than half of them $(53.67 \%, \mathrm{n}=336)$ being classified as serious from risk decision responsibility point of view. Following the risk decision diagram, all MMP notifications were treated as undecided between 2000 and $2011(50.59 \%, \mathrm{n}=512)$, with the remaining 500 being represented as not serious $(14.8 \%, \mathrm{n}=74)$, serious $(67.2 \%, \mathrm{n}=336)$ and the remaining $18 \%(n=90)$ undecided. This situation is quite specific and in the case of distribution status, where the lack of information $(14.6 \%, \mathrm{n}=148)$ is on third place as overall proportion (Fig. 2).
The largest category of MMP notifications concerned official controls on the internal market $(34.5 \%, \mathrm{n}=349)$, usually carried out at business operators (manufacturer, wholesaler, storage, retailer), which involved an inspection and possibly also sampling for the purpose of analysis.

Typically, three special types of MPP notifications were identified: company's own checks $(36.1 \%, \mathrm{n}=365)$, consumer complaints $(10.9 \%, \mathrm{n}=110)$ or food poisoning $(3.66 \%, n=37)$. In this time frame, only $5.44 \%(n=55)$ of MPP notifications concerned checks at the outer European Economic Area (EEA) borders at points of entry or border post. When the consignment was not accepted for import, a border rejection notification was issued, in some cases being taken samples for analysis for final decision (detained or released). From all border controls, statistics indicates more detained dairy products $(4.35 \%, \mathrm{n}=44)$ than released $(1.09 \%, n=11)$. Only a small number of MMP notifications were triggered by the official controls in a non-member country $(0.79 \%, n=8)$ or through RASFF network $(0.1 \%, \mathrm{n}=1)$. From 2000 to 2003 , no information on the notification basis could be collected for $8.6 \%$ $(n=87)$ of the MMP notification.

Associated data between distribution status and risk decision matrix revealed that more than half of the notifications $(59.48 \%, \mathrm{n}=602)$ were undecided, most affected dairy products being those possible distributed on the own market $(22.23 \%, \mathrm{n}=225)$ or to other Member States' markets $(7.80 \%, \mathrm{n}=79)$ (Table 1$)$. 


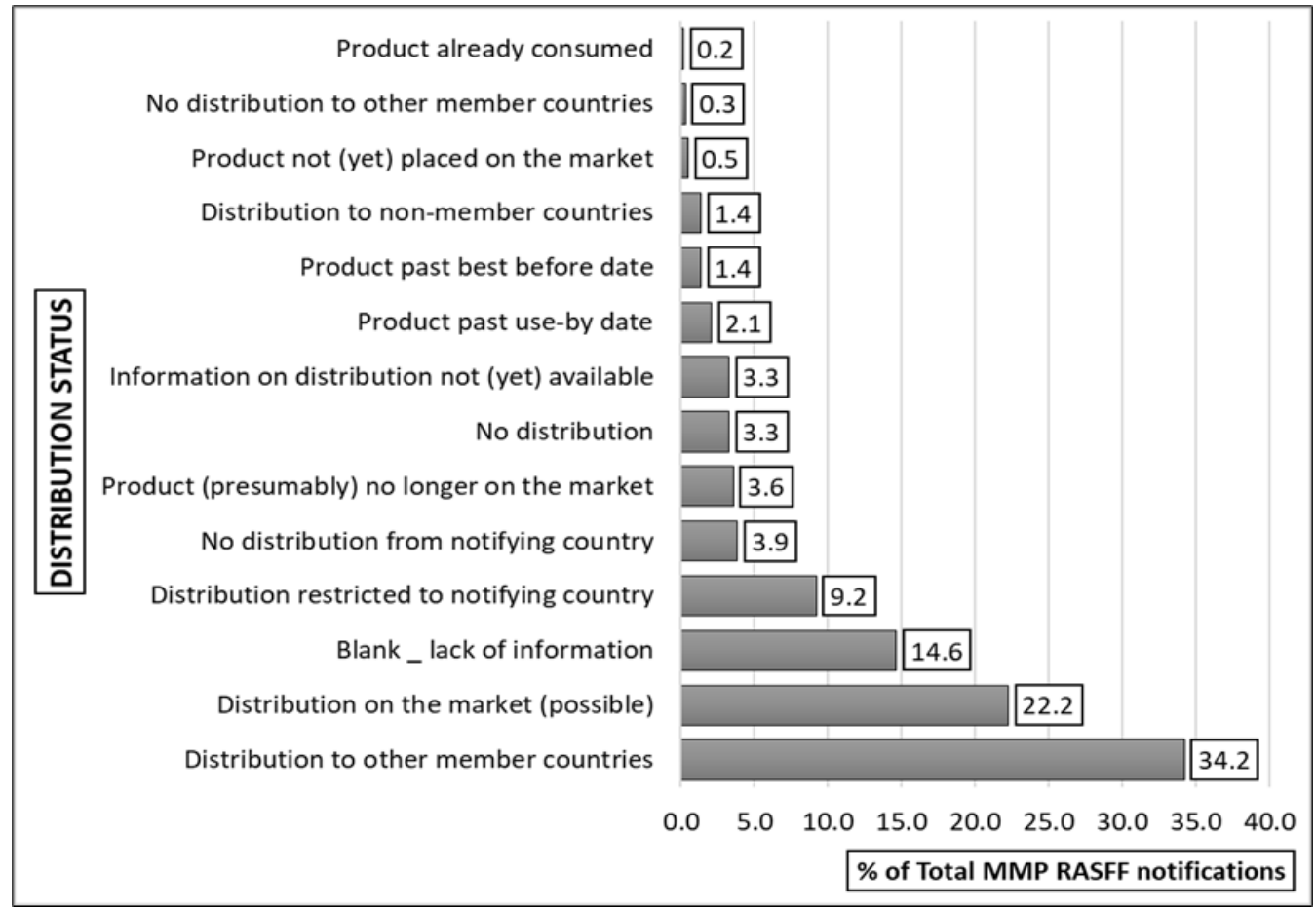

Figure 2. Distribution status of MMP RASFF notifications $(\mathrm{n}=1012)$

Table 1. MMP RASFF original notifications, by distribution status and risk decision

\begin{tabular}{lcccr}
\hline \multicolumn{1}{c}{ Distribution status } & \multicolumn{2}{c}{ Risk decision } & SUM \\
\hline Distribution on the market (possible) & not serious & serious & undecided & 225 \\
Distribution restricted to notifying country & 11 & 31 & 225 & $\mathbf{9 3}$ \\
Distribution to non-member countries & & 8 & 6 & $\mathbf{1 4}$ \\
Distribution to other member countries & 41 & 226 & 79 & $\mathbf{3 4 6}$ \\
Information on distribution not (yet) available & 4 & 7 & 22 & $\mathbf{3 3}$ \\
No distribution & 2 & 1 & 30 & $\mathbf{3 3}$ \\
No distribution from notifying country & 3 & 33 & 3 & 39 \\
No distribution to other member countries & & 2 & 1 & 3 \\
Product (presumably) no longer on the market & 9 & 25 & 2 & $\mathbf{3 6}$ \\
Product already consumed & & & 2 & 2 \\
Product not (yet) placed on the market & 1 & 2 & 2 & $\mathbf{5}$ \\
Product past best before date & 2 & & 12 & $\mathbf{1 4}$ \\
Product past use-by date & 1 & 1 & 19 & $\mathbf{2 1}$ \\
Blank_lack of information & & & $\mathbf{1 4 8}$ & $\mathbf{1 0 1 2}$ \\
\hline SUM & $\mathbf{7 4}$ & $\mathbf{3 3 6}$ & $\mathbf{6 0 2}$ &
\end{tabular}

c) MMP RASFF notifications cases $(\mathrm{N}=1043)$ c1) MMP RASFF notifications: origin \& country of notification

99\% of all original MMP RASFF notifications studied referred to an MMP food type, with an output of 1043 cases. France and Italy were notifying countries in almost half of these notifications (France $32.79 \%, \mathrm{n}=342$; Italy $13.90 \%, \mathrm{n}=145)$, followed by Germany $(11.03 \%, \mathrm{n}=115)$, all three countries accounted for $57.72 \%$ of all cases. Belgium, Netherlands, Spain, United Kingdom, Lithuania, Poland, Austria and Denmark have, as a group, a share quota of $23.49 \%$ (with less than $5 \%$ each: between $2.01 \div 4.79 \%$ ) of all MMP RASFF cases, as country of origin, while the remaining 196 notifications (18.79\%) came from 43 countries worldwide, each with less than $2 \%$ share quota (Fig. 3, Table 2)

Top three main key players are among the most populated EU28 countries and also among those with the highest gross national product at market prices. This could be part of explaining their RASFF notification activities, but trade relations and also country-specific differences in knowledge and related efforts in national food monitoring systems could play an important role (LÜTH et al [12]). 


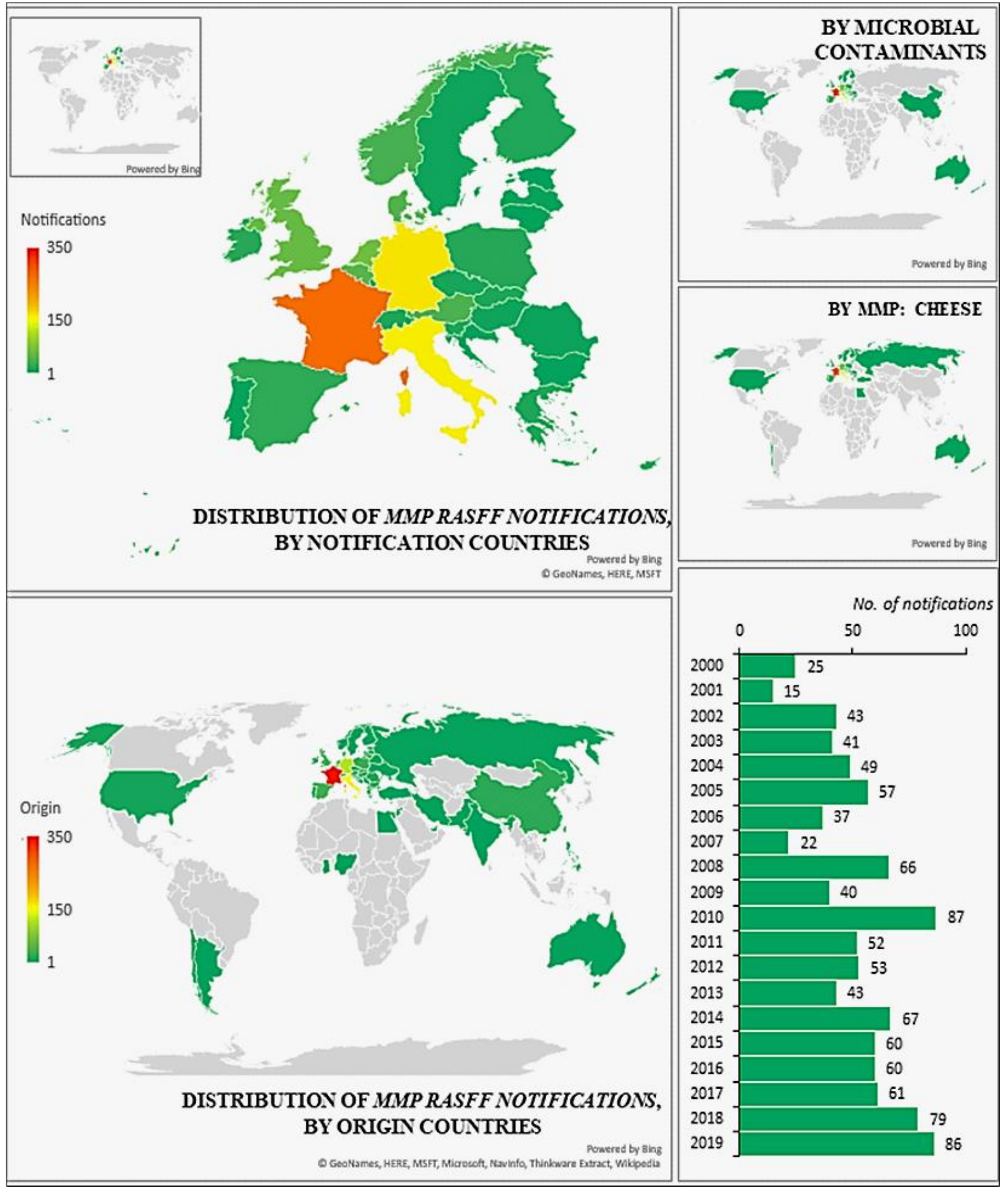

Figure 3. Distribution status of MMP RASFF notifications between $2000 \div 2020$, by origin \& country of notification, microbial contaminants and dairy product type: cheese. 
Table 2. MMP RASFF notifications between $2000 \div 2020$, by origin \& notification country

\begin{tabular}{|c|c|c|c|c|c|c|c|c|c|c|c|c|c|c|c|c|c|c|c|c|c|c|c|c|c|c|c|c|c|c|c|}
\hline \multirow{2}{*}{$\begin{array}{l}\text { Country } \\
\text { of origin }\end{array}$} & \multicolumn{30}{|c|}{ Country of notification } & \multirow{2}{*}{ sum } \\
\hline & AT & BE & BG & $\mathrm{CH}$ & $\mathrm{CY}$ & $\mathrm{CZ}$ & DE & DK & $\mathrm{EE}$ & ES & $\mathbf{F I}$ & FR & GB & GR & HR & HU & IE & IT & LT & LU & LV & MT & NL & NO & PL & PT & RO & SE & SI & SK & \\
\hline AE & & & & & & & & & & & & & & & & & & & & & & & & 1 & & & & 1 & & & 2 \\
\hline AN & & & & & & & 1 & & & & & & & & & & & & & & & & & & & & & & & & 1 \\
\hline AR & & & & & & & & & & 1 & & & & & & & & & & & & & & & & & & & & & 1 \\
\hline AT & 11 & & & & & 1 & 1 & & & & & & & & & & & 7 & & & & & 2 & & & & & & 1 & & 23 \\
\hline$A U$ & & & & & 1 & & & & & & & & & & & & & & & & & 1 & & & & & & & & & 2 \\
\hline BA & & & & & & & & & & & & & & & 1 & & & & & & & & & & & & & & & & 1 \\
\hline BE & & 26 & & & & & 4 & & & & & 9 & 5 & & & & 1 & 1 & & 1 & & & 3 & & & & & & & & 50 \\
\hline BG & & & & & 1 & & & 3 & & & & 1 & & & & & & & & & & & & & & & 1 & 1 & & & 7 \\
\hline BY & & & & & & & & & & & & & & & & & & & & & & & & & & & 1 & & & & 1 \\
\hline $\mathrm{CH}$ & & & & 1 & & & 6 & & & & & 3 & 1 & & & & & 4 & & & & & & & & & & & & & 15 \\
\hline $\mathrm{CL}$ & & & & & & & & & & & & & 1 & & & & & & & & & & & & & & & & & & 1 \\
\hline $\mathrm{CN}$ & 2 & & & & & & & & & 2 & & & 3 & & & 2 & & 7 & & & & & & & & & & & & 2 & 18 \\
\hline $\mathrm{CY}$ & & & & & 2 & & & & & & & & & & & & & & & & & & & & & & & & & & 2 \\
\hline $\mathrm{CZ}$ & & & & & & 3 & & & & & & & & & & 2 & & & & & & & & & 1 & & & & & 2 & 8 \\
\hline DE & 4 & 1 & 1 & & 2 & 2 & 43 & 7 & & 3 & 1 & 2 & 4 & 1 & 1 & & 1 & 33 & & 1 & & 1 & 2 & 2 & 1 & & & 1 & 1 & & 115 \\
\hline DK & & 1 & & & & & 3 & 12 & & & & & 3 & & & & & 1 & & & & & 1 & & & & & & & & 21 \\
\hline EE & & & & & & & 4 & & 1 & & 3 & & & & & & & & & & & & 2 & & & & & & & & 10 \\
\hline EG & & & & & 1 & & & & & & & & & & & & & & & & & & & & & & & & & & 1 \\
\hline ES & & & & & & & 1 & 2 & & 9 & 1 & 4 & 1 & & & & 1 & 3 & & 1 & & & 5 & & & 1 & & & & & 29 \\
\hline FI & & & & & & & & & & & 3 & & 1 & & & & & & & & & & & & & & & & & & 4 \\
\hline FR & 3 & 8 & & 4 & & 1 & 48 & 4 & & & 1 & 203 & 9 & 1 & & & 1 & 21 & & 2 & & 1 & 14 & 17 & 1 & 1 & & 2 & & & 342 \\
\hline GB & 1 & & & & 1 & & 1 & 2 & & & & 1 & 17 & & & & 1 & 1 & & & & 2 & 2 & & & & & & & & 29 \\
\hline GH & & & & & 1 & & & & & & & & & & & & & & & & & & & & & & & & & & 1 \\
\hline GR & & 1 & & & 2 & & 3 & & & & & & 1 & 4 & & & & 1 & & & & & & 1 & & & & & & & 13 \\
\hline HR & & & & & & & & & & & & & & & & & & & & & & & & & & & & & 7 & & 7 \\
\hline HU & & & & & & & 1 & & & & 1 & & & & & & & 9 & & & & & & & & & & & 1 & & 12 \\
\hline IE & & & & & 1 & & & & & & & & & & & & 10 & & & & & & & & & & & & & & 11 \\
\hline IL & & & & & & & & & & & & 4 & & & & & & & & & & & & & & & & & & & 4 \\
\hline IN & & & & & & & & & & & & & & 1 & & & & & & & & & & & & & & & & & 1 \\
\hline IR & & & & & & & & & & & & & & & & & & 2 & & & & & & 1 & & & & & & & 3 \\
\hline IT & 13 & 2 & & 7 & & 1 & 23 & 1 & & 1 & 1 & 37 & 3 & 1 & & & & 49 & & & & & & 5 & & & & & 1 & & 145 \\
\hline JO & & & & & 1 & & & & & & & & & & & & & & & & & & & & & & & & & & 1 \\
\hline LT & & & & & & & 19 & & & & & 1 & & & & & 1 & & & & 3 & & 1 & & & & & & & & 25 \\
\hline LV & & & & & & & 1 & & & & 1 & & & & & & & & & & 1 & & & & & & & & & & 3 \\
\hline MK & & & & & & & & & & & & & & 1 & & & & 1 & & & & & & & & & & & & & 2 \\
\hline NG & & & & & 1 & & & & & & & & & & & & & & & & & & & & & & & & & & 1 \\
\hline NL & & 2 & & & & & 4 & 7 & & & & 3 & 1 & & & & & 1 & 1 & & & & 24 & & & & & & & & 43 \\
\hline No & & & & & & & & & & & & & & & & & & & & & & & & 2 & & & & & & & 2 \\
\hline NZ & & 2 & & & & & & & & & & & & & & & & & & & & & 1 & 1 & & & & & & & 4 \\
\hline $\mathrm{PH}$ & & & & & & & & & & & & & 1 & & & & & & & & & & & & & & & & & & 1 \\
\hline PK & & & & & & & & & & & & & & 1 & & & & & & & & & & & & & & & & & 1 \\
\hline PL & & & & & & 1 & 1 & 1 & & & 1 & & 1 & & & 1 & & 4 & 1 & & & & 2 & & 8 & & 1 & & & 3 & 25 \\
\hline PT & & & & & & & & & & 3 & & 1 & & & & & & & & & & & & & & 2 & & & & & 6 \\
\hline RO & 1 & & 1 & & & & & & & & & & & 1 & & & & 8 & & & & & & & & & 2 & & & & 13 \\
\hline RS & & & & & & & & & & & & & & & 1 & & & & & & & & & & & & & & & & 1 \\
\hline RU & & & & & & & & & & & & 1 & & & & & & & 1 & & & & & & 1 & & & & & & 3 \\
\hline SE & & & & & & & & & & & & & & & & & & & & & & & 1 & & & & & 1 & & & 2 \\
\hline SI & & & & & & & & & & & & & & & & & & 6 & & & & & & & & & & & 1 & 1 & 8 \\
\hline SK & & & & & & & & & & & & 1 & & & & 1 & & & & & & & & & 2 & & & & & 4 & 8 \\
\hline TR & & & & & & & & & & & & & & & & & & & & & & & & & 1 & & & & & & 1 \\
\hline TW & & & & & & & 1 & & & & & & & & & & & & & & & & & & & & & & & & 1 \\
\hline UA & & & & & & & & & & & & 1 & 1 & & & & & & & & & & & & & & & & & & 2 \\
\hline UNK & & & & & & 1 & & & & & & 1 & & & & & & & & & & & & & & & & & & & 2 \\
\hline US & & & & & & & & & & & & & 2 & 1 & & & & 1 & & & & & 2 & 2 & & & & & & & 8 \\
\hline SUM & 35 & 43 & 2 & 12 & 14 & 10 & 165 & 39 & 1 & 19 & 13 & 273 & 55 & 12 & 3 & 6 & 16 & 160 & 3 & 5 & 4 & 5 & 62 & 32 & 15 & 4 & 5 & 6 & 12 & 12 & 1043 \\
\hline
\end{tabular}

$\mathrm{AE}=$ United Arab Emirates, $\mathrm{AN}=$ Netherlands Antilles, $\mathrm{AT}=$ Austria, $\mathrm{AR}=$ Argentina, $\mathrm{AT}=$ Austria, $\mathrm{AU}=\mathrm{Australia}, \mathrm{BA}=\mathrm{B}$ osnia $\&$ Herzegovina, $\mathrm{BE}=$ Belgium, $\mathrm{BG}=$ Bulgaria, $\mathrm{BY}=$ Belarus, $\mathrm{CH}=\mathrm{S}$ witzerland, $\mathrm{CL}=\mathrm{Chile}, \mathrm{CN}=\mathrm{China}, \mathrm{CY}=\mathrm{Cyprus}, \mathrm{CZ}=\mathrm{Czech}$ Republic, DE=Germany, DK=Denmark, EE=Estonia, EG=Egypt, ES=Spain, FI=Finland, FR=France, GB=United Kingdom, $\mathrm{GH}=$ Ghana, GR=Greece, HR=Croatia, HU=Hungary, IE=Ireland, IL=Israel, IN=India, IR=Iran, IT=Italy, JO=Jordan, LT=Lithuania, LV=Latvia, LU=Luxembourg, MK=Macedonia, MT=Malta, NG=Nigeria, NL=Netherlands, NO=Norway , NZ=New Zealand, PH=Philippines, PK=Pakistan, PL=Poland, PT=Portugal, RO=Romania, RS=Serbia, RU=Russian Federation, SE=Sweden, SI=Slovenia, SK=Slovakia, TR=Turkey, TW=Taiwan, UA=Ukraine, US=United States of America, UNK=Unknown. 
c2) MMP RASFF notifications: products affected \& hazards

The notified dairy products were grouped into nine categories, the dominant being cheese $(68,74 \%, n=717)$. The remaining notification cases involved a number of dairy products at least 10 times less than the prevalent one, as follows: milk and dairy products $(8.44 \%, \mathrm{n}=88)$, processed liquid milk $(5.85 \%, \mathrm{n}=61)$, yoghurts $(5.37 \%$, $\mathrm{n}=56)$, butters $(2.40 \%, \mathrm{n}=25)$, dried milks: powders and concentrate $(4.51 \%, \mathrm{n}=47)$, raw milk $(3.46, \mathrm{n}=36)$, processed milk products $(0.58 \%, \mathrm{n}=6)$ and creams $(0.67 \%, \mathrm{n}=7)$.

Within cheese category, even though the product variety was high, it can be said that the products were mostly affected by microbial contaminants due to the lack of process control in both primary and secondary production areas: milk hygiene for specific raw / unpasteurized milk cheeses (bacterial infection) or heat treatment stability for pasteurized milk cheeses (OLIVER et al [21]; VELÁZQUEZ-ORDOÑEZ et al [35]). The most commonly notified cheese was by type as: fresh soft (Burrata, Ricotta); soft, semi-soft (Camembert, Bethmale, Halloumi, Brie, Gorgonzola, Mascarpone, Herve, Reblochon, Roquefort, White types) and extra hard, hard, semi-hard (Grana, Gouda, Blue, Cheddar, Emmenthal, Lavistown, Grana), their distribution, by origin, being described in Fig. 3.

Other milk and dairy products referred in particular to: caseins, ice-cream, milk-based desserts (shakes, flavored milk drinks, puddings), processed milk formula for children, whey powder, curdled milk and kefir. The butter category included different end product status: like frozen, spreadable, traditional from raw and pasteurized milk.

There were 16 types of hazards affecting the dairy products referred to above, Fig. 4 illustrating the relationship between them, roughly similar to what is reported in RASFF. Here, the presence of majority of the microbial contaminants $(68.36 \%, \mathrm{n}=713)$ was correlated with various types of cheese $(n=602)$, particularly soft cheese, followed by processed liquid milk products $(\mathrm{n}=25)$, other milk \& dairy products $(n=24)$, raw milk $(n=19)$, yoghurts $(n=16)$, butters $(n=12)$, dried milk: powders and concentrate $(\mathrm{n}=11)$ and creams $(\mathrm{n}=4)$.

The most prevalent microbial etiological agents emphasized in our survey were: Escherichia spp. [coli, shigatoxin \& verotoxin producing]; Listeria spp. [monocytogenes, innocua]; Salmonella spp. [enteritica (arizonae, anatum, brandenburg, bredeney, blockley C2, derby, diarizonae, dublin, enteritidis, houtenae (VI), meleagridis, oranienburg, paratyphi B, typhimurium, isangi, kedougou, panama, rissen), group $B$, agama, jedburgh, mbandaka, montevideo, stourbridge]; Bacillus spp. [cereus (diarrheal enterotoxin: NHE \& emetic toxin), subtilis]; Shigella spp.; Enterobacteriaceae; Campylobacter; Spoilage; Yeasts; Moulds; Enterococcus faecalis; Cronobacter sakazakii; Aeromonas spp. [hydrophila \& caviae], Staphylococcus spp. [aureus, coagulase-positive], Brucella spp.; Mycobacterium tuberculosis, Pseudomonas [fluorescens, aeruginosa] and
Botulinum toxin. Their worldwide distribution, by origin, is shown in Fig. 3.

A recent paper on microbial contamination of dairy products outlines their main causative sources: mammary gland health status, animal herd health status, production environment, and land-water source production (VELÁZQUEZ-ORDOÑEZ et al, [35]). A similar article, with an earlier time-scale analysis of the European Dairy Supply Chain, details all microbiological hazards notified in the EU during 2009-2014 (VAN ASSELT et al [32]), none of the above-mentioned microbial hazards being new.

The foreign bodies identified were: glass fragments; metal (fragments, particles, nail, wires, fiber strings, paperclip); plastic (fragments, particles of anthracite color and irregular shape, packaging foil, rubber pieces, strands, pasty transparent lumps of various sizes); wood splinters; diverse impurities (sharp fragments, Teflon, electric cable fragments, particles \& synthetic fibers, undissolved melting salts from the production process, lactose crystals, unidentified particles) and insects (live, mites, snout beetle). The detection of foreign bodies has doubled over the last 10 years compared to the period $2000-2009$ ( $n=82,30.49 \%$ vs. $69.51 \%$ ).

Root cause analyzes have usually shown the contamination pathways of MMP RASFF notified cases, which were introduced due to lack of control during processing regarding: machinery or parts of equipment, packaging materials, personnel hygiene rules (warning jewelry), or presence in raw materials. Visual observations, metal detection or X-ray inspection systems could usually prevent inadequacies in Good Manufacturing Practices, as part of the HACCP study (VAN SCHOTHORST \& KLEISS [34]; PEARISO [24]).

In the case of adulteration and fraud $(4.31 \%, n=45)$, the most common food safety issues were: existence of fraudulent or improper health certificate(s); exceed Best Before Date; dates of BBD changed; presence of mineral oil; absence of a health mark; unauthorized - establishment, operator, transit, imports, for human consumption or tampering by inserting needles. It's the first of all hazards in the "border rejection" classification.

At the notified dairy products, the altered organoleptic characteristics $(4.51 \%, \mathrm{n}=47)$ referred to coagulation, modified color (blue, orange, dark green and pink), abnormal smell and taste (chemical, tongue burning, sour smell, bitter taste, transparent solution with chlorine or oil taste) and spoilage. More than half of them were related with microbial contamination.

In the context of allergens $(1.44 \%, \mathrm{n}=44)$, the majority of food safety problems related to the accuracy of the labeling for allergenic ingredients, as defined in EU Reg. (EU) 1169/2011, and the improper presence of allergen traces, as follows: presence of cow milk in products lactose free or dairy products with a different milk source (other than cow); allergic reaction; presence of egg, celery, gluten or lactose traces or undeclared ingredients as: cow milk casein, egg, fish, gluten, lactose, milk \& egg, mustard \& celery or walnut. 


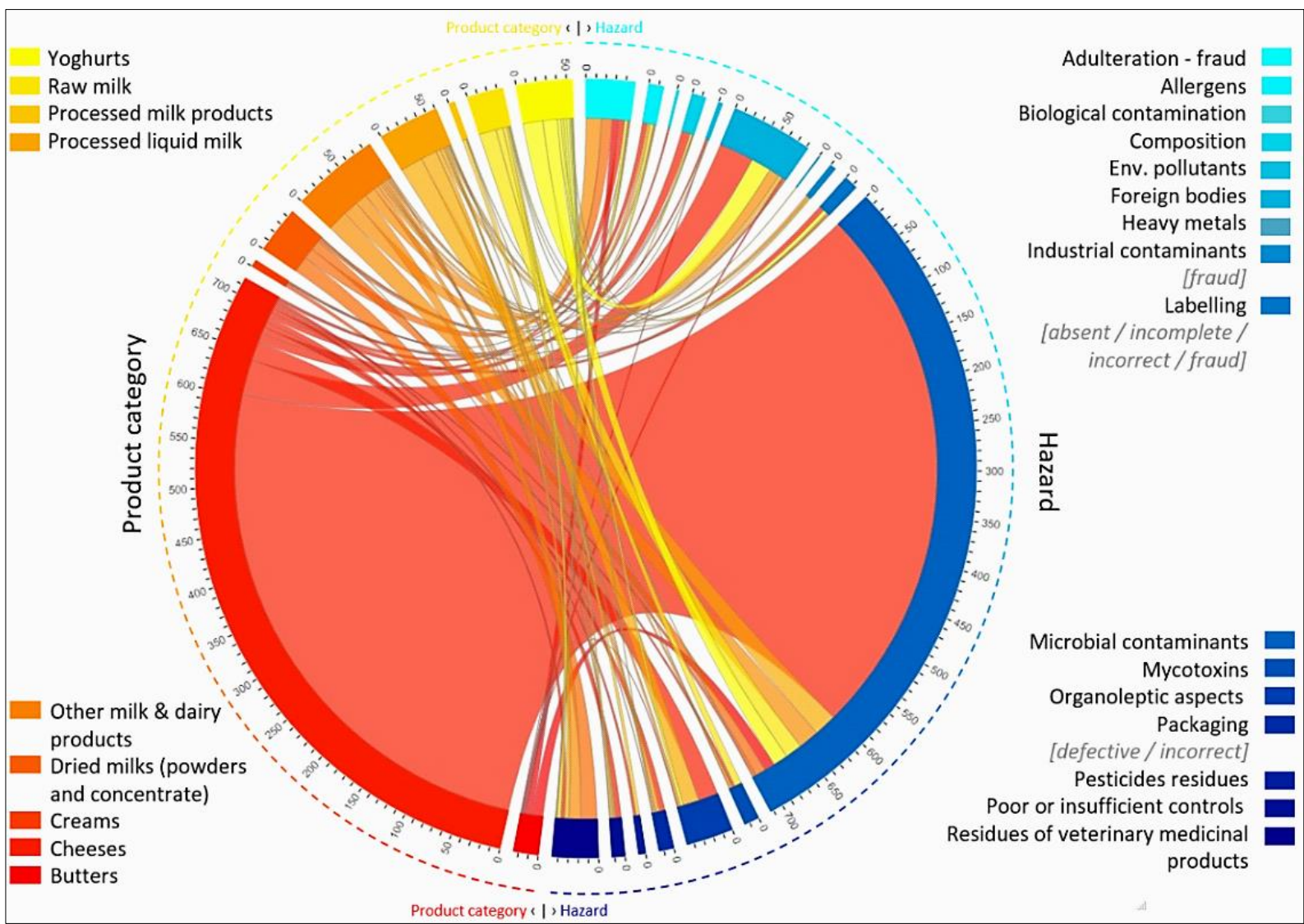

Figure 4. Product categories of MMP RASFF notifications, by hazard, $2000 \div 2020$. Arc lengths on the outer circle are proportional to the number of notifications of a product category or to the number of notifications affected by a specific hazard category.

The most recurring problems referring to dairy products packaging $(1.44 \%, \mathrm{n}=15)$ were related to bulging, damaged lids, defective fault affecting the neck of the bottle, vacuum leakage and inadequate sealing during production, while for the labeling category $(1.34 \%, n=14)$ the most notified issues were: the absence of expiry date; modified or incorrect expiry dates (two separate BBDs, incorrect Use By Date printing) or incorrect labeling of allergic ingredients (as milk).

In almost all cases, the notified mycotoxins were those from feed, particularly aflatoxins M1, which were transferred to milk. Because of their dietary importance regarding the total intake, their acceptable limits in dairy products is regulated by law (Reg. (EC) 1881/2006). Our findings are consistent with KLETER et al [15] conclusion, that $93 \%$ of all RASFF mycotoxin notifications were for aflatoxins. Imported products mainly contaminate feed in Europe (SCHATZMAYR \& STREIT [31]).

The composition category $(1.34 \%, n=14)$ identified the existence of a variety of unregulated substances or other ones high rates, such as: unauthorized presence of mineral oil, ammonium chloride, dehydroacetic acid [E265], erythrosine [E127], orthophenylphenol [E231], sorbic acid [E200], unidentified greasy substance; high content of natamycin, polyphosphates [E452], undeclared lysozyme [E1105] or hydrogen peroxide as residue from detergents / disinfectants due to poor or insufficient controls $(0.38 \%$, $\mathrm{n}=4$ ).

Veterinary drugs are prescribed to treat animal diseases, manly for mastitis (OLIVER et al, [22]). They have prescribed withdrawal periods, as laid down in Directive 2001/82/EC, before farmers can reseal the milk. These withdrawal periods were established to prevent antibiotic residues in animal products above MRLs as set out in Regulation (EU) 37/2010 and Directive 96/23/EC. Besides regulatory drugs, prohibited compounds are sometimes found in milk. Chloramphenicol is the most frequently reported compound (84.8\%) from a total of 46 MMP RASFF notified cases. In the last 10 years the number has drastically declined, year 2002 having the highest MMP RASFF notifications on this aspect.

All the illegal imports of milk drinks containing melamine have been included in industrial contaminants category $(0.58 \%, n=6)$, all cases being referred at 20082009 China melamine crisis.

Dioxins and dioxin-like polychlorobiphenyls were the environmental contaminants $(0.38 \%, \mathrm{n}=4)$ identified in cheese, raw milk and butter, all the products withdrawn from the market due to their negative effect (WHO 2016). Their presence results from the use of phosphate fertilizers, the application of contaminated material, such as sewage sludge or industrial waste, and the atmospheric deposition 
of nearby industrial activities (LOGONATHAN et al [17]; LUTZ et al [18]; NAG [20]; HOOGENBOOM \& FINKGREMMELS [11]). Such contaminants can bioaccumulate in livestock (RYCHEN et al, [28]) for a long time (NAG, [19]). Dioxins and PCBs in raw milk and dairy products have declined in the EU over the years, the last case being notified in 2015 through RASFF (EFSA [7]; HOOGENBOOM \& FINK-GREMMELS [11]).

The notified pesticide residues $(0.67 \%, n=7)$ from the categories of organochlorine (OCPs) and hexachlorocyclohexanes were mainly from Romania $(n=6)$. One case involved raticides from Denmark. The use of these pesticides has been restricted and is now banned in most countries (PICÓ [26]).

The food safety issue for biological contamination $(0.19 \%, n=2)$ was the presence of histamine in cheese, with final withdrawal from the market measures taken.

For heavy metals was a singular case $(0.1 \%)$, when RASFF system has alerted the presence of lead in a sheep's raw milk from Italy.

As has been shown, the second most frequent hazards were chemical hazards. Most often, they enter the chain at primary production (BAUMAN et al [2]), either through ingestion of contaminated feed or veterinary medicines. With the exception of pesticides and heavy metals, a substantial part of these contaminants appears to be associated with adulteration / fraud episodes, which can occur at various stages along the dairy supply chain. Several notable examples are: the presence of dioxin in animal feed due to the illegal and improper use of contaminated technical fats (KUPFERSCHMIDT [16]; VAN ASSELT [32]), the incident of furazolidone in Dutch animal feed (DIJKSMA 2014 cited by VAN ASSELT et al [32]) or the 2008 melamine crisis in China (CHEN [5]; PEI et al [25]; CHEN et al [6]).

To control all these hazards, the industry establishes continuous intervention measures, such as the implementation of GLOBAL Good Agricultural Practices (GLOBAL G.A.P.) or Hazard Analysis Critical Control Points (HACCP) systems.

c3) MMP RASFF notifications basis, notifications types and action taken

Most of MMP RASFF notifications were based on company's own checks $(35.47 \%, \mathrm{n}=370)$, followed by official controls on the market $(34.32 \%, n=358)$. In our dataset, notifications following company's own checks did not appear before 2003. In the last decade, the number of them has increased more than six times $(n=370,13.24 \%$ vs. $86.76 \%$ ) compared to the last one, most probably due to the alignment of normative food safety legislation within EU28 countries. From these, most were notified by France (26.17\%, $n=273)$, followed by Germany $(15.82 \%, n=165)$ and Italy $(15.34 \%, \mathrm{n}=160)$.

Of the key players in the notifications, only for France the overall percentage of notifications based on the company's own checks clearly exceeded that of notifications based on official market controls (167 vs. 53), while in Germany and Italy it was quite the opposite (44 versus 56 and 23 versus 83 , respectively).
While the number of notifications on the basis of the company's own controls fluctuated between 1 and 53 per year from 2003 to 2020 (with a turning point in 2008, $n=22$ ), notifications based on official controls on the market first emerged in 2003 and during this time there was a declining trend (from 25 to 19 in 2020). Over the last 12 years (starting to 2008) food poisoning has been listed as a notification basis, with a total of 40 cases. In eight notifications, a RASFF notification was issued as a result of an official control in a non-EU member state. From all notifications transmitted as a result of border control $(n=59)$, only $18.64 \%$ of them were released after further review. $8.25 \%(\mathrm{n}=86)$ of the notifications issued pursuant to these criteria could not be included in one category due to lack of information (between 2000 and 2003).

Of all 1043 MMP RASFF notifications, more than half $(56.95 \%)$ ended up withdrawal from customers or market recall. Destruction methods were implemented only for $7.96 \%(n=83)$, mainly due to official market controls or border control. Another notifiable action taken (out of 25 forms of actions), with a share quota above $2 \%$ each and $91.18 \%$ overall, have been: informing recipients $(3.55 \%)$, public warning - press release $(2.97 \%)$, seizure $(2.68 \%)$, official detention $(2.59 \%)$, informing authorities $(2.11 \%)$ and return to consignor $(2.11 \%)$.

In summary, this paper provides an overview of the most important microbiological, chemical and physical hazards encountered in the European dairy supply chain notified via RASFF. The effectiveness in the control of these hazards is a critical challenge for the dairy industry, and its relevance has been expressed through them recurrence.

\section{Conclusion}

In general, most of the information found in the scientific literature on food safety hazards associated with dairy cows and cow milk products, this being expressed and in the number of MMP RASFF notifications. France, Germany and Italy are responsible for more than half of the MMP notifications, all three countries with a share quota of $57.72 \%$ of all notified cases, as origin source.

Comparing various food safety hazards, microbiological hazards $(68.4 \%)$ were notified more often in dairy products than chemical or physical ones. Listeria monocytogenes, Salmonella spp. and Escherichia coli (Shigatoxin \& Verotoxin producing) were the main etiologic agents, particularly linked to cheese. Aflatoxin M1, environmental pollutants (primarily dioxin and dioxinlike compounds), and veterinary drugs were the most significant chemical hazards for dairy products, based on data surveillance and literature review. Metal, glass and plastic fragments are the principal physical hazards in the notified dairy products. Cheese was the most notified of all dairy products $(84.43 \%)$, especially those made from raw milk. Notifications was usually based on company's own check (35.47\%), official controls on the market (34.32\%) as well as consumer complaints $(11.60 \%)$. The notification types were mainly alert $(58.20 \%)$ and information $(21 \%)$. Dairy products were not consistently distributed $(35 \%)$ due to the restriction of distribution to the notifying country, 
the possibility of distribution to the market or to the lack of information regarding the distribution status. A risk decision was not usually made, $60.21 \%$ of all notifications being undecided. The taken actions included mainly recalls and withdrawals from clients and final consumers $(56.95 \%)$ or destruction $(7.96 \%)$.

The results of this study can be used to prioritize and target research areas to identify key food safety topics, in particular fraudulent ones, such as adulterants and food fraud practices in dairy products, to raise the awareness of the final consumer and to promote and strengthen food safety legislation, with a focus on the European dairy sector.

\section{References}

1. BANACH JL, STRATAKOU I, VAN DER FELSKLERX HJ, DEN BESTEN HMW, ZWIETERING $\mathrm{MH}$, European alerting and monitoring data as inputs for the risk assessment of microbiological and chemical hazards in spices and herbs. Food Control. 2016; 69:237-249. doi.org/10.1016/j.foodcont.2016.04.010.

2. BAUMAN CA, BARKEMA HW, DUBUC J, KEEFE GP, KELTON DF. Canadian National Dairy Study: Herd-level milk quality. Journal of Dairy Science. 2018; 101(3):2679-2691. DOI:10.3168/jds.2017-13336.

3. BÁNÁTI D, KLAUS B. 30 years of the rapid alert system for food and feed. Eur Food Feed Law Rev. 2010; 5(1):10-21.

4. BOUZEMBRAK Y, MARVIN HJP. Prediction of food fraud type using data from Rapid Alert System for Food and Feed (RASFF) and Bayesian network modelling. Food Control. 2016; 61:180-187. doi:10.1016/ j.foodcont.2015.09.026.

5. CHEN J-S. What can we learn from the 2008 melamine crisis in China? Biomed Environ Sci. 2009; 22(2):10911. doi.org/10.1016/S0895-3988(09)60031-3.

6. CHEN C, ZHANG J, DELAURENTIS T. Quality control in food supply chain management: an analytical model and case study of the adulterated milk incident in China. Int J Prod Econ. 2014; 152:188-99. doi.org/10.1016/j.ijpe.2013.12.016.

7. EFSA. Update of the monitoring of levels of dioxins and PCBs in food and feed. EFSA J. 2012c; 10:2832.

8. European Commission. 30 years of keeping consumers safe Rapid Alert System for Food and Feed (RASFF). 2009; online: https://ec.europa.eu/food/sites/food/files/ safety/docs/rasff_30_booklet_en.pdf

9. European Commission RASFF portal. Retrieved from https://webgate.ec.europa.eu/rasffwindow/portal/ ?event $=$ SearchForm\&cleanSearch $=1$ Accessed date: January $6^{\text {th }} 2020$.

10. HIRSCHAUER N, ZWOLL S. Understanding and managing behavioral risks: the case of malpractice in poultry production. Eur J Law Econ. 2008; 26(1):2760. doi:10.1007/s10657-008-9051-0.

11. HOOGENBOOM R, FINK-GREMMELS J. Animal feed contamination by dioxins, polychlorinated biphenyls (PCBs) and brominated flame retardants. In: FinkGremmes L, editor. Animal feed contamination. Cambridge, UK: Woodhead Publishing. 2012; 131182. doi.org/10.1533/9780857093615.2.131.
12. LÜTH S, BOONEA I, KLETAA S, SASCHA AL DAHOUKA D. Analysis of RASFF notifications on food products contaminated with Listeria monocytogenes reveals options for improvement in the rapid alert system for food and feed. Food Control. 2019; 96:479-487. doi.org/10.1016/j.foodcont.2018.09.033.

13. HRUSKA K, FRANEK M. Rapid alert system for food and feed: the semi carbazide notifications. Vet Med. 2009; 54(11):561-564, available online: http://vri.cz/ docs/vetmed/54-11-561.pdf, Accessed December 5th 2019.

14. JAUD M, CADOT O, SUWA-EISENMANN A. Do food scares explain supplier concentration? An analysis of EU agri-food imports. Eur Rev Agric Econ. 2013; 40(5):873-890. doi:10.1093/erae/jbs038.

15. KLETER GA, PRANDINI A, FILIPPI L, MARVIN HJP. Identification of potentially emerging food safety issues by analysis of reports published by the European Community's Rapid Alert System for Food and Feed (RASFF) during a four-year period. Food Chem Toxicol. 2009; 47(5):932-950. doi:10.1016/j.fct.2007. 12.022 .

16. KUPFERSCHMIDT K. Dioxin scandal triggers food debate in Germany. Can Med Assoc J. 2011; 183(4):E221-2. DOI: 10.1503/cmaj.109-3801.

17. LOGONATHAN P, HEDLEY MJ, GRACE ND. Pasture soils contaminated with fertilizer-derived cadmium and fluorine: livestock effects. Rev Environ Contam T. 2008; 192:29-66. DOI: 10.1007/978-0-38771724-1_2.

18. LUTZ S, FEIDT C, MONTEAU F, RYCHEN G et al. Effect of exposure to soil-bound polycyclic aromatic hydrocarbons on milk contaminations of parent compounds and their monohydroxylated metabolites. J Agric Food Chem. 2006; 54(1):263-268. doi.org/ 10.1021/jf0522210.

19. NAG SK. Contaminants in milk: routes of contamination, analytical techniques and methods of control. In: Griffiths MW, editor. Improving the safety and quality of milk volume 1: milk production and processing. Oxford, UK: Woodhead Publishing Ltd. 2010a; 146-78.

20. NAG SK. Pesticides, veterinary residues and other contaminants in milk. In: Griffiths MW, editor. Improving the safety and quality of milk volume 1: milk production and processing. Oxford, UK: Woodhead Publishing Ltd. 2010b; 113-145.

21. OLIVER SP, BOOR KJ, MURPHY SC, MURINDA SE. Food safety hazards associated with consumption of raw milk. Foodborne Pathogens and Disease. 2009; 6(7):793-806. doi: 10.1089/fpd.2009.0302.

22. OLIVER SP, MURINDA SE, JAYARAO BM. Impact of antibiotic use in adult dairy cows on antimicrobial resistance of veterinary and human pathogens: a comprehensive review. Foodborne Pathogen and Dis. 2011; 8:337-355. doi:10.1089/fpd.2010.0730.

23. PARISI S, BARONE C, SHARMA RK, Chemistry and Food Safety in the EU. The Rapid Alert System for Food and Feed (RASFF). In: Chemistry of Foods, 2016; 47-62. DOI 10.1007/978-3-319-33393-9_3. 
24. PEARISO D. Preventing foreign material contamination of foods. Hoboken, USA: Wiley-Blackwell. 2007; 306 pages. DOI:10.1002/9780470277713.

25. PEI X, TANDON A, ALLDRICK A, GIORGI L et al. The China melamine milk scandal and its implications for food safety regulation. Food Pol. 2011; 36(3):412420. doi.org/10.1016/j.foodpol.2011.03.008.

26. PICÓ Y. Food contaminants and residue analysis. Amsterdam, the Netherlands: Elsevier. 2008.

27. PIGŁOWSKI M, Pathogenic and non-pathogenic microorganisms in the Rapid Alert System for Food and Feed. Int. J. Environ. Res. Public Health. 2019; 16, 477, 1-19. doi:10.3390/ijerph160304772017.

28. RYCHEN G, JURJANZ S, TOUSSAINT H, FEIDT C. Dairy ruminant exposure to persistent organic pollutants and excretion to milk. Animal. 2008; 2(2):312323. doi: 10.1017/S1751731107001139.

29. THOMSON B, POMS R, ROSE M. Incidents and impacts of unwanted chemicals in food and feeds. Qual Assur Saf Crop. 2012; 4: 77-92. doi.org/10.1111/ j.1757-837X.2012.00129.x.

30. TROPEA F. The future of the EU dairy sector after the end of milk quotas. European Parliamentary Research Service (PE 564.359). 2015; available online: http://www.europarl.europa.eu/RegData/etudes/BRIE/ 2015/564359/EPRS_BRI(2015)564359_EN.pdf

31. SCHATZMAYR G, STREIT E. Global occurrence of mycotoxins in the food and feed chain: facts and figures. World Mycotoxin J. 2013; 6:213-222. DOI: 10.3920/WMJ2013.1572.

32. VAN ASSELT ED, VAN DER FELS-KLERX HJ. MARVIN HJP. VAN BOKHORST-VAN DE VEEN et al. Overview of Food Safety Hazards in the European Dairy Supply Chain. Compr Rev Food Sci F. 2016; 00:1-17. doi: 10.1111/1541-4337.12245.

33. VAN DE BRUG FJ, LUCAS LUIJCKX NB, CNOSSEN HJ, HOUBEN GF. Early signals for emerging food safety risks: from past cases to future identification. Food Control. 2014; 39: 75-86. doi.org/ 10.1016/j.foodcont.2013.10.038.

34. VAN SCHOTHORST M, KLEISS T. HACCP in the dairy industry. Food Control. 1994; 5:162-6, available online: https://www.aua.gr/skandamis/Literature/ Enotita_7-Theoria/FOOD_CON_5,182-186.pdf

35. VELÁZQUEZ-ORDOÑEZ V, VALLADARESCARRANZA B, TENORIO-BORROTO E, TALAVERA-ROJAS $M$ et al. Microbial contamination in milk quality and health risk of the consumers of raw milk and dairy products. In: Nutrition in Health and Disease - Our Challenges Now and Forthcoming Time. IntechOpen; 2019; DOI: http://dx.doi.org/10.5772/ intechopen.86182.

36. WORLD HEALTH ORGANIZATION. Dioxins and their effects on human health. 2016; available online: https://www.who.int/en/news-room/fact-sheets/ detail/dioxins-and-their-effects-on-human-health

37. ZHANG Y, WELLS E, CHEN J. Analyzing Food safety alerts in European Union Rapid Alerts Systems for Food and Feed. In: Committee on strengthening core elements of regulatory systems in developing Countries; Board on global health; Board on Health Sciences Policy; Institute of Medicine; Riviere JE, Buckley GJ (eds) Ensuring safe foods and medical products through stronger regulatory systems abroad. National Academies Press, Washington, D.C. 2012; available online: https://www.nap.edu/read/13296/ chapter/16

38. *** COUNCIL DIRECTIVE 96/23/EC of 29 April 1996 on measures to monitor certain substances and residues thereof in live animals and animal products and repealing Directives 85/358/EEC and 86/469/EEC and Decisions 89/187/EEC and 91/664/EEC

39. *** COUNCIL DIRECTIVE 2001/82/EC of the European Parliament and of the Council of 6 November 2001 on the Community code relating to veterinary medicinal products, OJ L 311, 28.11.2001, 1-66.

40. *** COMMISSION REGULATION (EC) No 1881/ 2006 of 19 December 2006 setting maximum levels for certain contaminants in foodstuffs. OJ L 364, 20.12. 2006, 5-24.

41. *** Commission Regulation (EU) No 37/2010 of 22 December 2009 on pharmacologically active substances and their classification regarding maximum residue limits in foodstuffs of animal origin. OJ L 15, 20.1.2010, 1-72.

42. $* * *$ COMMISSION REGULATION (EU) No 16/2011 of 10 January 2011 laying down implementing measures for the Rapid alert system for food and feed. OJ L 6, 11.1.2011, 7-10.

43. *** REGULATION (EC) No 178/2002 of the European Parliament and of the Council of 28 January 2002 laying down the general principles and requirements of food law, establishing the European Food Safety Authority and laying down procedures in matters of food safety. OJ L 31, 1.2.2002, 1-24.

44. *** REGULATION (EC) No 882/2004 of the European Parliament and of the Council of 29 April 2004 on official controls performed to ensure the verification of compliance with feed and food law, animal health and animal welfare rules. OJ L 165, 30.4.2004, 1-141.

45. *** REGULATION (EC) No 853/2004 of the European Parliament and of the Council of 29 April 2004 laying down specific hygiene rules for food of animal origin. OJ L 139, 30.4.2004, 55-205.

46. *** REGULATION (EU) No 1169/2011 of the European Parliament and of the Council of 25 October 2011 on the provision of food information to consumers, amending Regulations (EC) No 1924/2006 and (EC) No 1925/2006 of the European Parliament and of the Council, and repealing Commission Directive 87/250/ EEC, Council Directive 90/496/EEC, Commission Directive 1999/10/EC, Directive 2000/13/EC of the European Parliament and of the Council, Commission Directives 2002/67/EC and 2008/5/EC and Commission Regulation (EC) No 608/2004 Text with EEA relevance. OJ L 304, 22.11.2011, 18-6. 